テトラアせチル糊液酸オイゲノールェメテル

テトラアセチル粘液酸クロリド $3 \mathrm{~g}$, オイ乡゙;ール $3.8 \mathrm{~g}$, トルオール $10 \mathrm{cc}$, 前例

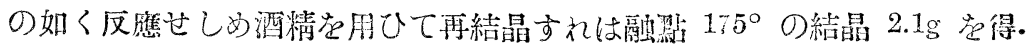
原素分析

物 筫 $0.0510 \mathrm{~g}$ 宸骖 $0.1141 \mathrm{~g} \quad$ 水 $0.027 \mathrm{~g} \quad \mathrm{C} \% 61.04 \quad \mathrm{Ir} \% 6.08$

理馀数 $\mathrm{C}_{14} \mathrm{H}_{[6} \mathrm{O}_{10}\left(\mathrm{C}_{10} \mathrm{H}_{11} \mathrm{O}_{2}\right)_{2} \quad 60.88 \quad 5.71$

樐化數测定

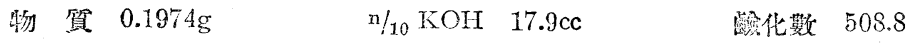

$$
\begin{aligned}
& \text { 理詥数 } \nabla_{11} \mathrm{H}_{10} \mathrm{O}_{10}\left(\mathrm{C}_{10} \mathrm{H}_{11} \mathrm{O}_{2}\right)_{2}
\end{aligned}
$$

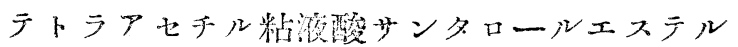

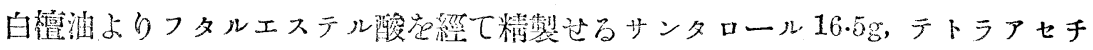

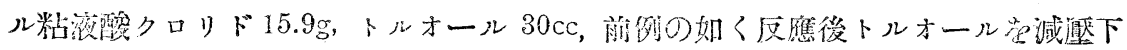

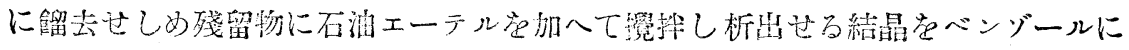

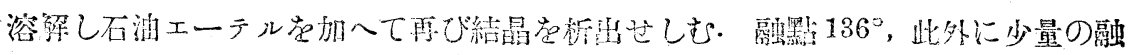

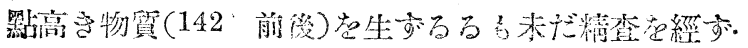

原素分析

$$
\begin{aligned}
& \begin{array}{llllll}
\text { 質 } 0.0502 \mathrm{~g} & \text { 宸酸 } 0.1091 \mathrm{~g} \text { 水 } 0.0301 \mathrm{~g} & \mathrm{C} \% & 59.27 & \mathrm{H} \% & 0.71
\end{array} \\
& \text { 理論較· } \mathrm{C}_{29} \mathrm{H}_{40} \mathrm{O}_{12} \\
& 59.92 \quad 6.94
\end{aligned}
$$

\title{
滴定
}

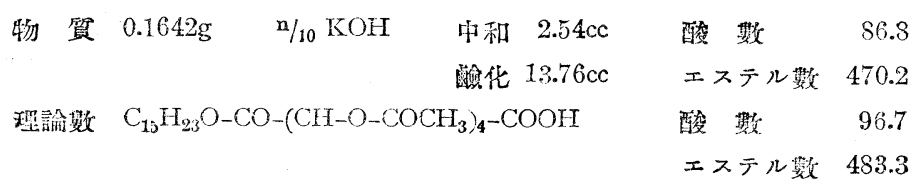

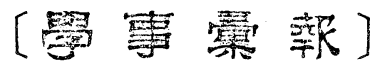

\section{I. 哭機化學 有袎化學}

アミノマロン酸エステルの製法 R. Locquin \& V. Cerchez: Compt. rend.

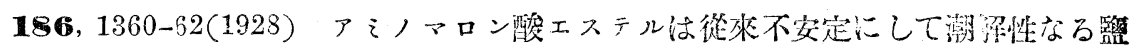
酸監として僅に記載されたるに過ぎす。著著等は本エステルそ著量に县つ純粹に

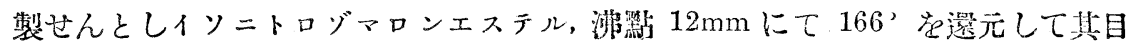
的を達し得たり・本品はマロン酸エステル1 モルを 3 モルの醰酸に溶解せしめ之 に亞确酸ソーダ 3 モルの水溶汻を加〜 $90 \%$ 得量を以て製し得. 之の還元はア ルぇニウム又はマグネシウムアマルガムを以て行ひ得, 即ち含水エーテル中に於 
て罯元しエーテル液ヶアルミニウムを洗滌したるエーテルと合しエーテル觉梁去

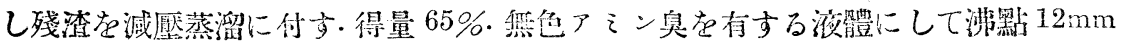

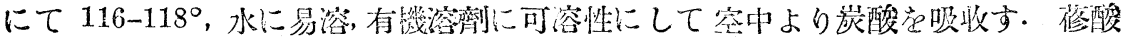

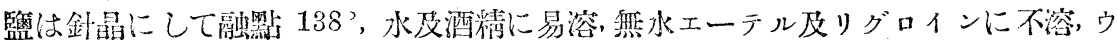

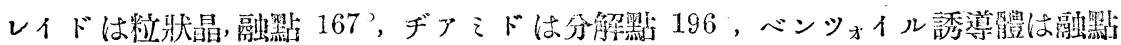
$61^{\circ}$ なり・アミノマロンエステルは熘ナトリウムに依りて置換され得る水素觉有 し其ナトリウム誘導體にハロダンアルキルを作用せしもる時はアルキル置換骾を 得べし. 即ちナトリウムエチラート或忠エーテル中に知けるナトリウムにアに，

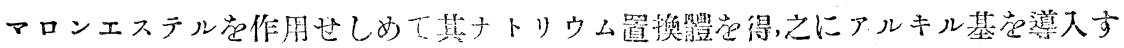

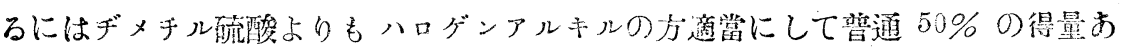

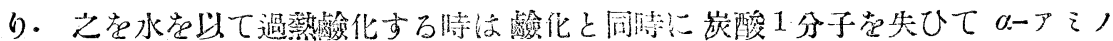
酸足生蓑。本法は はかくしてロイチン及フェニルララニン等觉合成し得たり・之に反しナトリウム

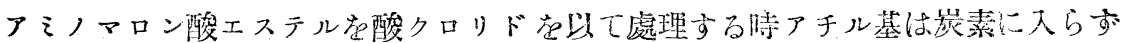

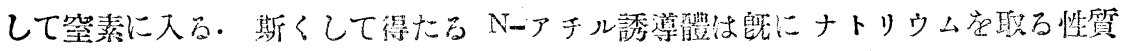
なし.

(管濽)

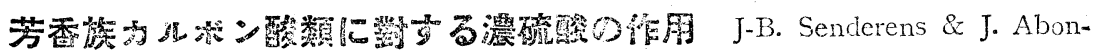

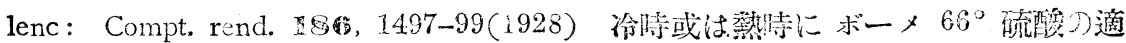

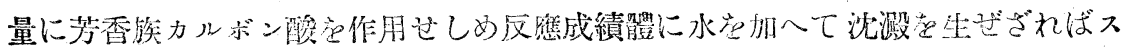
ルフォン化行はれたる證なり１）．安息香酸。此腰 1 分尼Bé $65^{\circ}$ 硫酸 8 分と混

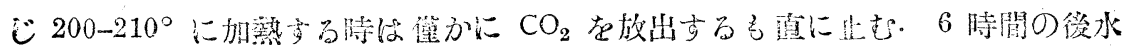

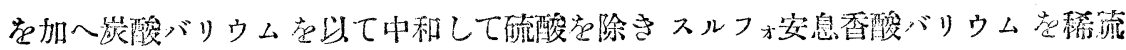

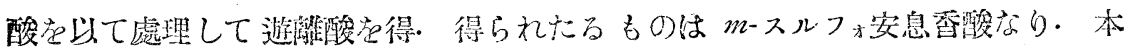

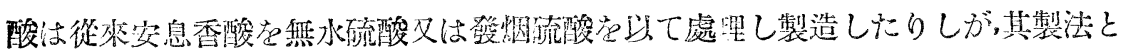

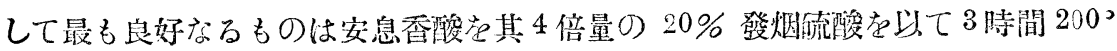

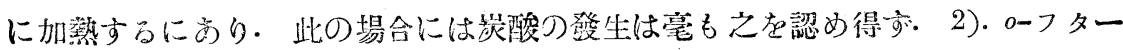

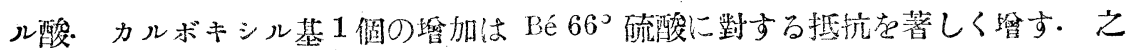

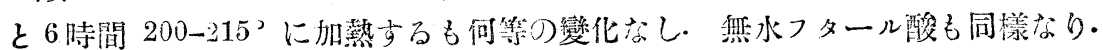

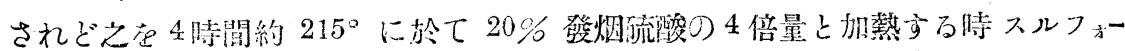

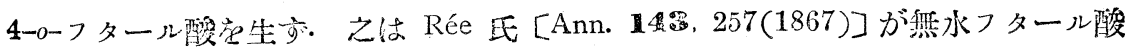
とピ口硫酸との混合物に 200-210 に於て6 封閒然水流睃蒸氣觉作用せしめて得 たるものと同一物質にして著苦等の法は Rée 氏去に比して簢單なり・3).トルイ 一ル酸. カルボキシル基と反對にメチル基つ存在は流渗の作用を容易ならしむ.

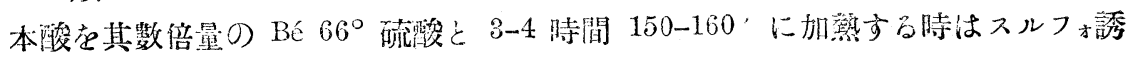

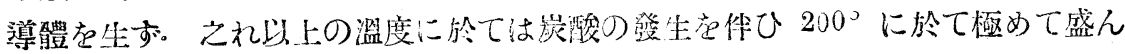


となる. $20 \%$ 發烟硫酸を用ふる時は溫度 $100^{\circ}$ 以下にて充分にして, より上高

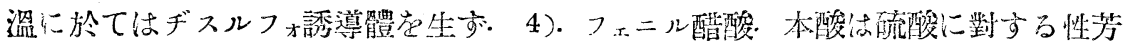

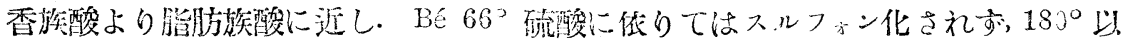

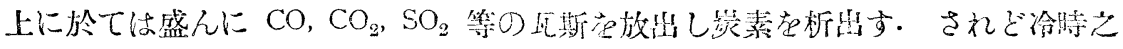

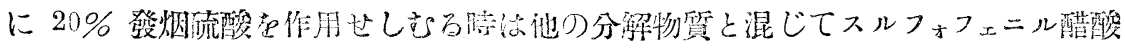
学生新。

(管罯)

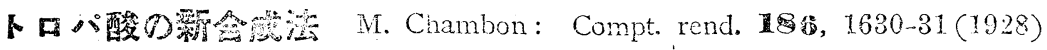
アトロパ酸よりする Ladenburg, Mc Kenzie \& Wood 氏等法 [J. Chem. Soc. 1 11

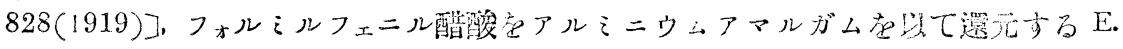

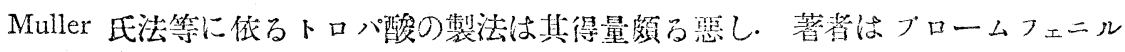

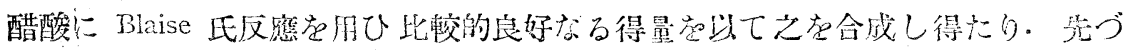

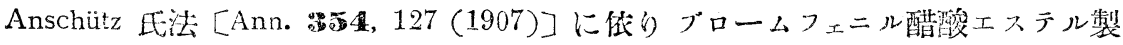

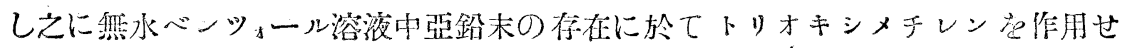

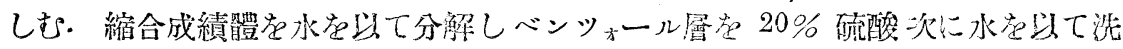

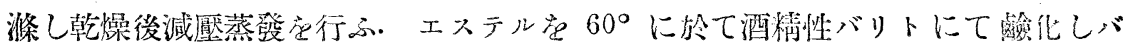

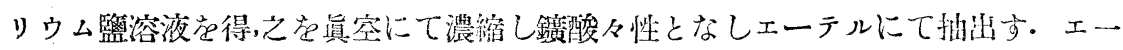

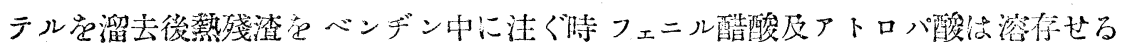

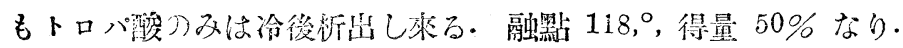

(管濢)

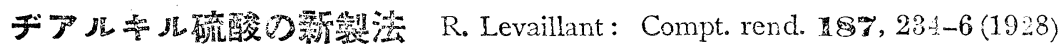
ヂアルキル硫睃の中ヂィチル硫酸俚簡單に良好なる得量な以て製し得るもヂェチ ル硫睃に到りては毁に其製造困難なり・著者はクロールォネフォン陖メチルエス

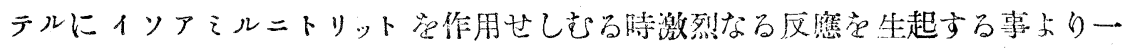
般に本反應を用ひてヂアルキル硫酸の製造に成功したり・師ち其反應次式の如 し. 生成ヂアルキル硫酸も亦亞硝酸アルキルと反應する在以てクロールスルフォ

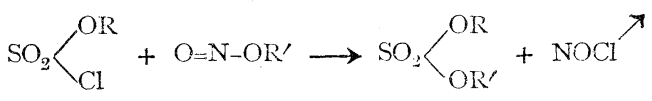

ン酸エステルの催淡性刺䇅息の消失を機として反應を中止せしさ・得量は一般に 50\%內外なり. 即ちヂメチル硫酸つ製造には不適なるもヂェチル硫覆つ製法とし ては從來の法よりも適賞なるものの如し. クロールスルフォン酸エチルエステル

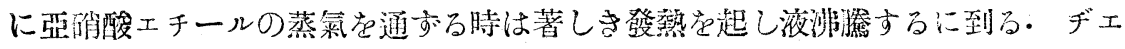
チル硫睃の製法に對してはクロールスルフォン酸エステルを80-900 の浴中に納 あ之に亞的酸エチルの蒸氮文通じ反應液の溫度を $100^{\circ}$ 附近に保たしむ. 之を越す 時は得量著しく低下す。例之クロールスルフォン酸エチル $434 \mathrm{~g}(3$ モ几) 觉還流冷

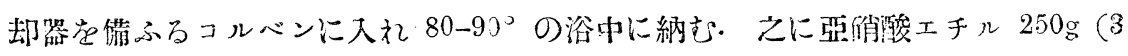




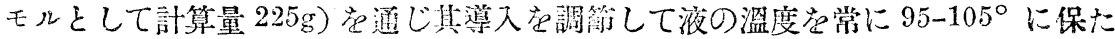

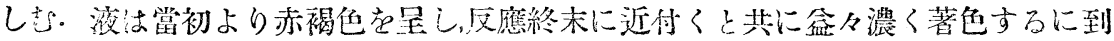

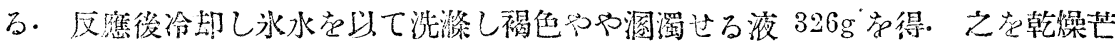

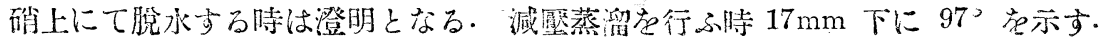
少量の初溜哭除き沸點 97-98'(15-17 mm) の器色澄明なる液 $255 \mathrm{~g}$ を得. 毁ち得 量理諭數の $55 \%$ なり。

（菅澤）

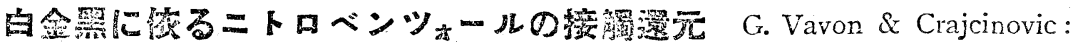

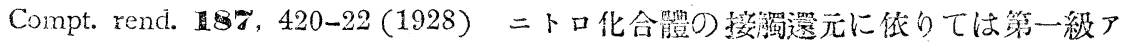

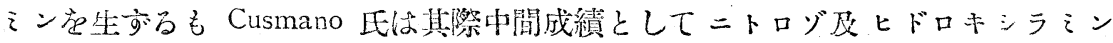

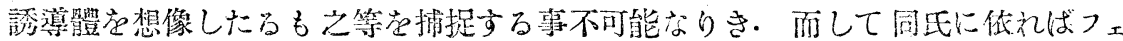

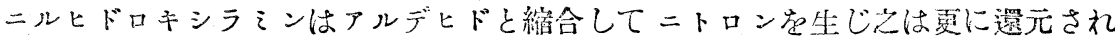

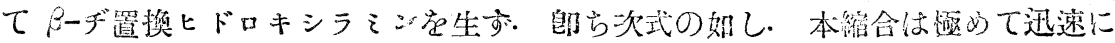

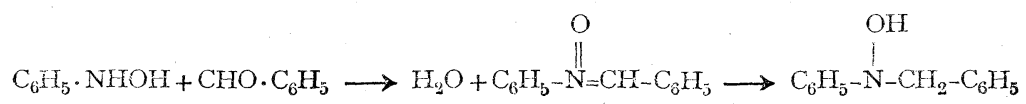

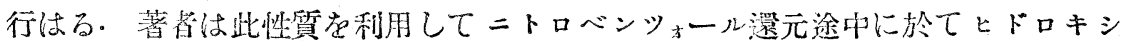
ラえン觉證明し得たり・ニトロベンツォール文びえと同量のベンツアルデヒドを

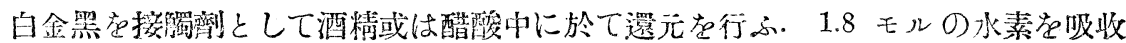

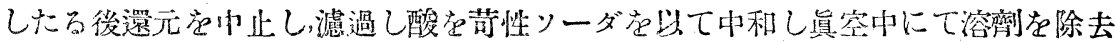

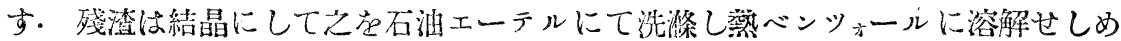

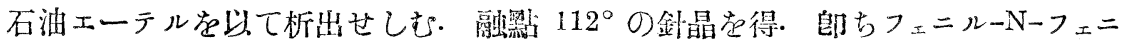
ルニトロンに一致し分析數もよく $\mathrm{C}_{13} \mathrm{H}_{11} \mathrm{ON}$ に一致す。更に還元苂續行し終結迄

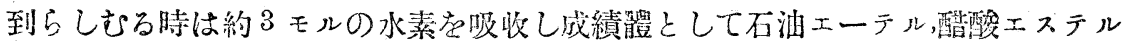
ふり雨結晶炎繰り返して $86^{\circ}$ のもの存得たり. 分析數べンチルフェニルヒドロキ シラン $\mathrm{C}_{13} \mathrm{H}_{13} \mathrm{ON}$ に一致す. ベンッァルデヒドの代りにピペロナールを用ふる時

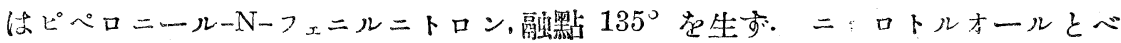

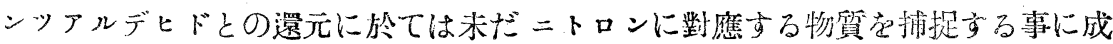
功し得亦。

（管澤）

デォダメチレン環の開裂法 F. Mauthner： J. pr. Ch. (2), 119, 74-6 (1928) ヂオキシメチレン環の開裂法には種々あるも著者は蟚に箊香族オキシケ トンエーテル類の開裂に用ひて良好なる結果贺得心る方法を竝に應用したり【子。 pr. Ch. (2), 1耳-137, 274 (1927)]. 即ち物翼を乾燥クロールベンツォールの十 數倍容に溶解し粉末監化アル

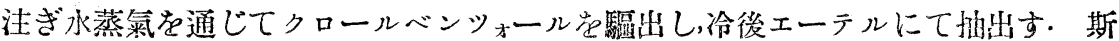
くしてアセトピペロン $3 \mathrm{~g}$ よりアセトブレッカテヒン $1.2 \mathrm{~g}$, ピペロニール酸 $3 \mathrm{~g}$ よ り $1.8 \mathrm{~g}$ のプロトカテヒュ酸を得たり・文此の外ブレッカテヒンー0ーカルボン酸は 
從來 Senhofer \& Brunner 氏等に依りブレンッカテヒンに炭酸アンモンを作用せ しめて製したるものなるが,著者の法足用ふる洔は工業的多量に製せらるるがアヤ コールーーカルボン酸より谷易に製するを得。其得量グアヤコールーーカルボン酸 $3 \mathrm{~g}$ より 0 ープロトカテヒュ酸 $1.2 \mathrm{~g} な り$.

(管覆)

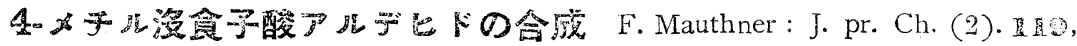

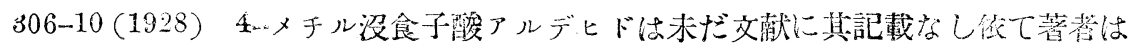
其合成艺行ひたり. Herzig \& Pollak 兩氏に依れば涩食子酸メチルエステルにデ

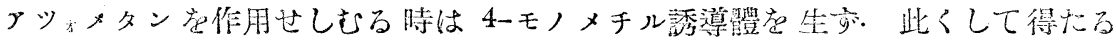

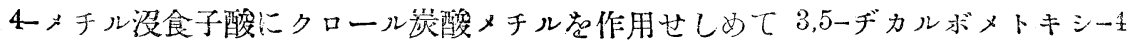

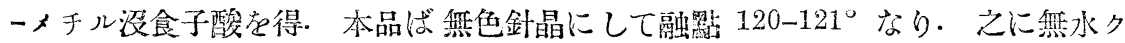

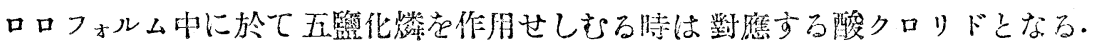
リグロインより再結晶せしもる封融踔 58-90 の無色釗晶として得らる。此クロ

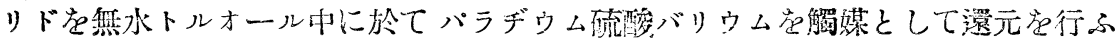

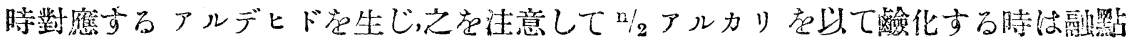

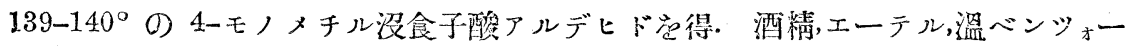
ルには易溶,冷ベンツォールには溶け易からず がニトロフェニルヒドラツォンは融 點 222-3’なり.

(管罯)

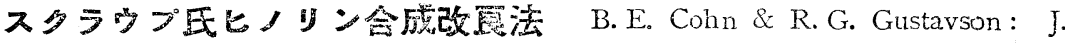
Am. Chem. Soc. 2709-11(1928) スクラウプ氏ヒノリン合成法の改良法徒從

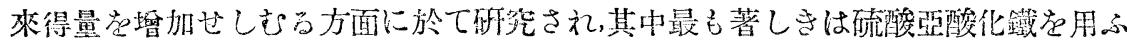

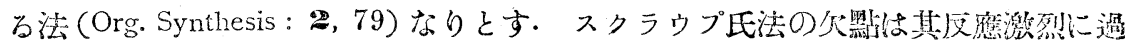

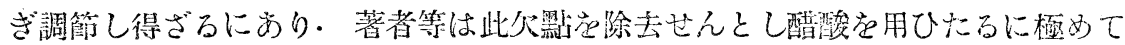

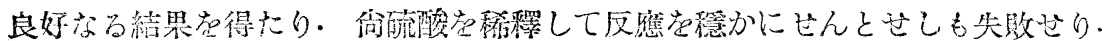
例之アニリン $38 \mathrm{~g}$, ニロベンツォール 24g, グリ七リン $100 \mathrm{~g}$, 醋酸(80\%) $60 \mathrm{cc}$,

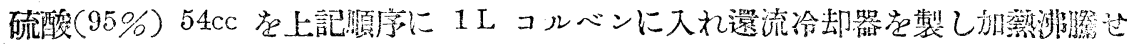

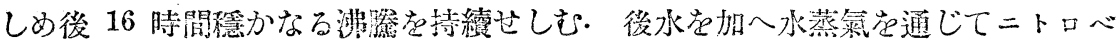

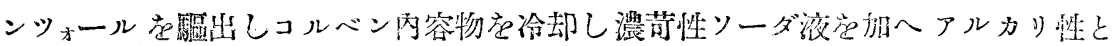

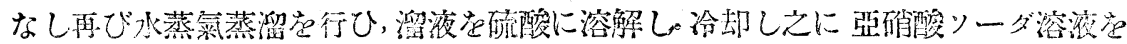

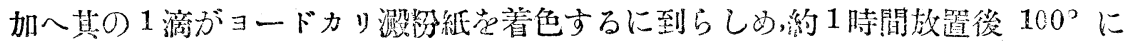

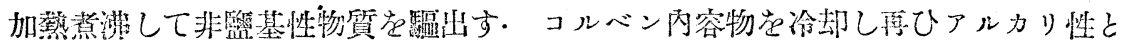
なし水蒸氣蒸溜炎行ひ,溜液をエーテルを以て括出しエーテルを溜去しヒノリンを

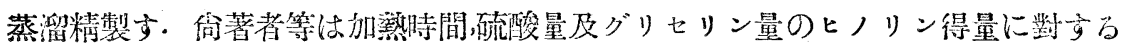

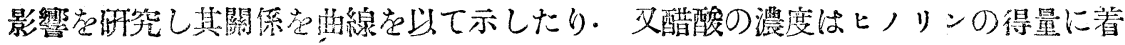
しき影篦なきが如し。

(菅摆)

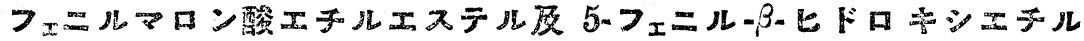


バルビツール酸の合成 W. L. Nelson \& L. H. Cretther : J. Am. chem. Soc. ฐ0，2753-82(1928）5-フェニルェチルバルビッール酸勘ちルミナールが着しき催 眠性を有するに拘はらずバルビッール酸アリル誘導艠の合成されざるは其製造容 易ならざるにあり・フェニルェチルバルビッール㖥の合成に關しては最近 Rising \& Zee 兩氏 [J. Am. chem. Soc. 199, 541(1927)]の報告わり. 著者等は面に別法 を以て其原料たるフェニルマロン酸エステルを合成し之虹源料として更に5-フェニ ルーアーオキシェチルバルビッール酸の合成に成功したり．フェニル醋酸エチルェス

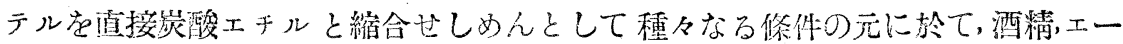
テル,ベンッォール等右溶㓩として金屬ナトリウムとナトリウムアミドに依り反應 せしめたるにエーテル或はベンッォール责用ひナトリウムに依りてのふ維合する も得量 $20 \%$ 内外にして製造目的に適せず. 次にベンチルチアニド,金屬ナトリウ ムルエーテルとクロール炭酸エチルの縮合觉試みたるに得量 $50 \%$ にして良好なら 亦. 次にエーテル中に於てベンチルチアニドとナトリウむアミドとより其ナトリ ウム化合物觉作り えに炭酸エチル觉作用せしめたるに其結果最良好にしてフェニ ルチアン醋酸エステルの得量 $70 \%$ に達す. 而してつェニルマロン睃エステルの

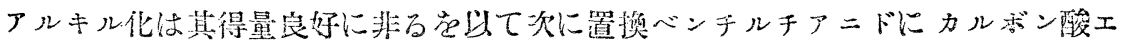
ステル苍揞入せんとしたるも何れも不成功に終りたり・フェニルチアン醌酸エス

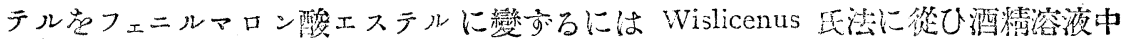

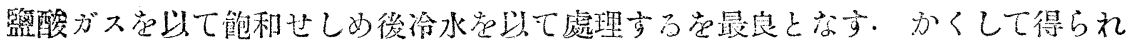

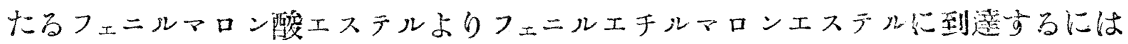

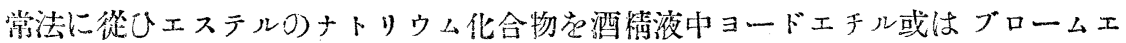
チルと處理するにあるも其際エステルの一部分解してフェニル醋酸エステル告生 亦万篇得量一般心良好ならす。何ナトリウムの過剩尼用ふる時はエステルは完全

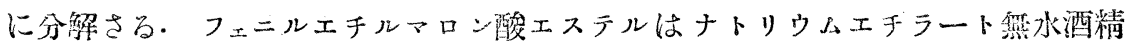

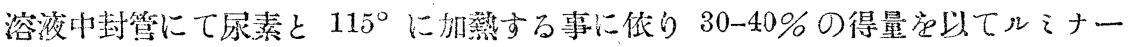
ル它生矛。万ーアーオキシェチルフェニルバルビッール酸を得んには先づフェニルーアー

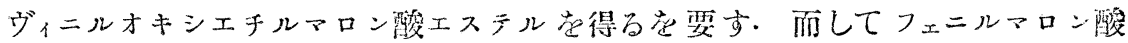
エステルとアークロールエチルヴィニルエーテルとの綪合は困難なりしもつェニル

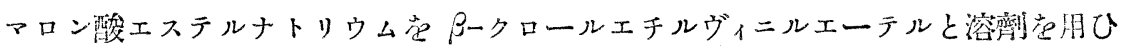

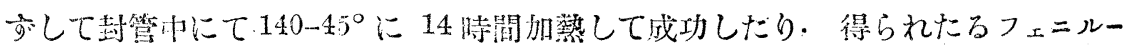
ヴィニルオキシェチルマロン慗エステルは沸點 $17 \mathrm{~mm} に$ にて 196-7, 得量 $52 \%$ な

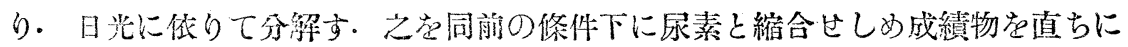

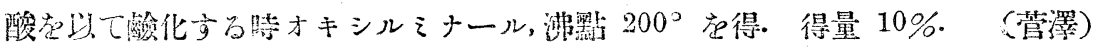

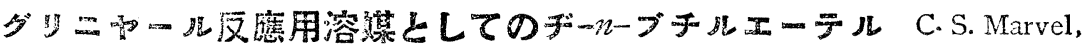
A. T. Blomquist \& L. E. Vaughn : J. Am. chem. Soc. 画, 810-12 (192\$) グリ 
ニャール反應に於てヂェチルェーテルよりも融黑の高き溶集さ必要とする事數次 なり・ヂークーデルェーテルは此の目的に對しては極少て適賞なる溶楳なるも從

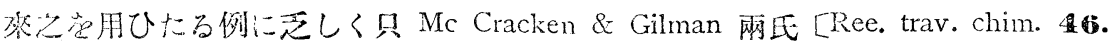
$463(1927)]$ はブロームベンツォールよりフェニルマグネシウムブロにド虔製する

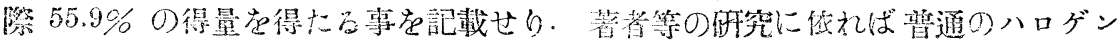

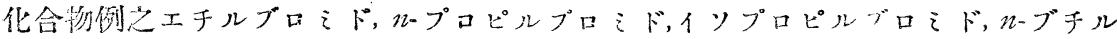

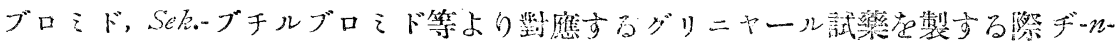

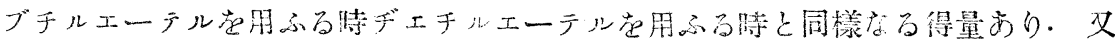

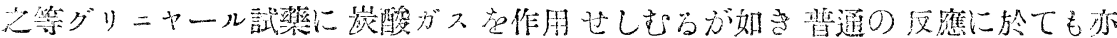

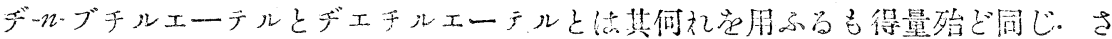

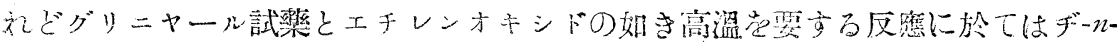

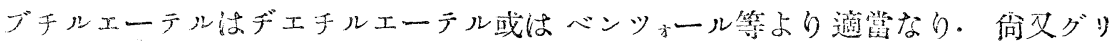
ニサール試藥とフォルムアルデヒドとより第一級アルコホル范製せんとするが如 き場合に於てもブチルエーテルは其融點高き箁パラフォルムアルデヒドの分解の

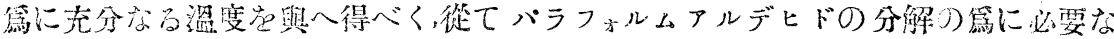

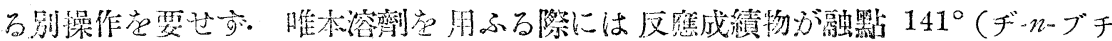

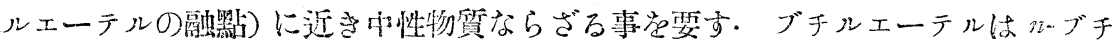

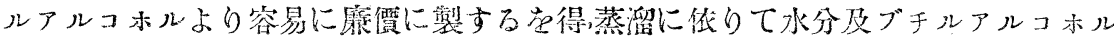

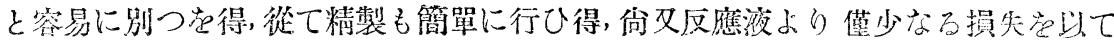
容易に包收する事觉得るな゙゙ェチルエーテルより優りたる默とす。

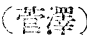

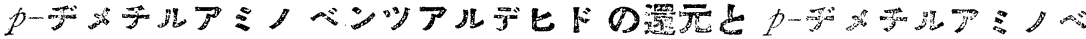

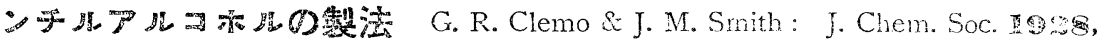

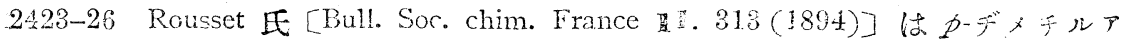

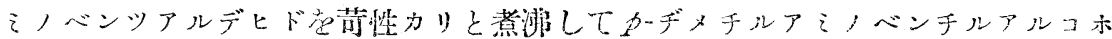

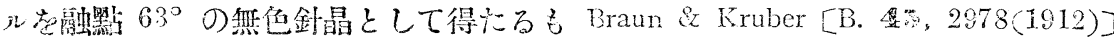

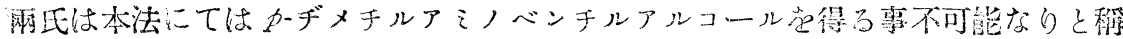

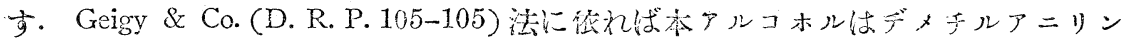
にフォルムアルデヒド党作用せしめて得らるべく, Braun \& Kruber 氏等も斯くし

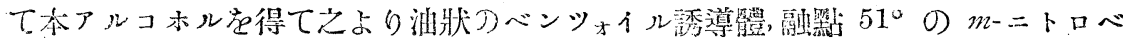

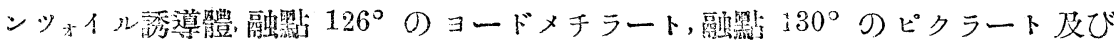

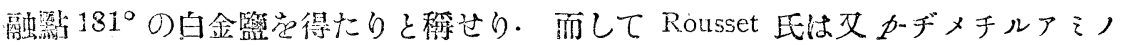

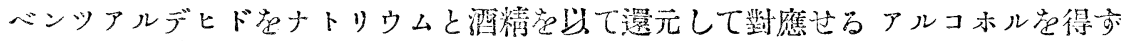

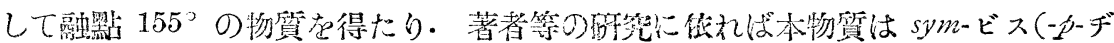
メチルアミノフェニル) エチレングリコール (I) 及 (II) の混合物にして, 此等の外

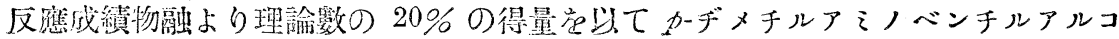




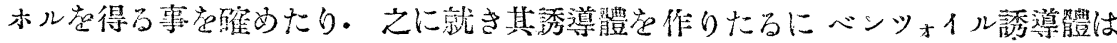

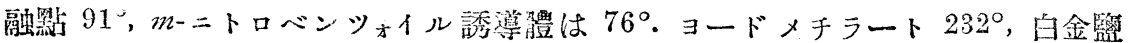

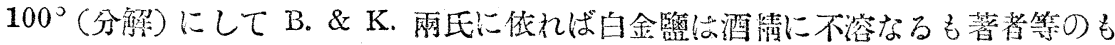

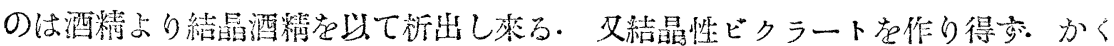

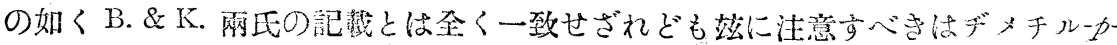

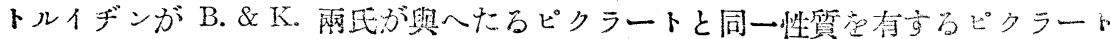

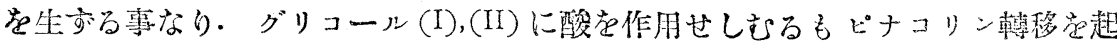

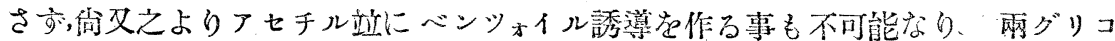
一ルの中融點 $113^{\circ}$ のものは多量に生じヂョードィチラート莡生弯るも他のグリ

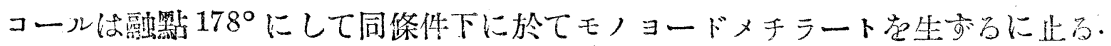

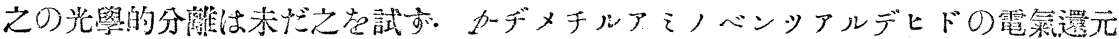
は䂠に Schepss 氏 [B. 盀6，2574(1913)]に依りて記载され杰法に依り41\%の

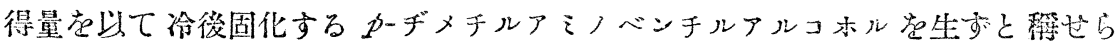

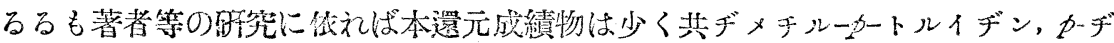

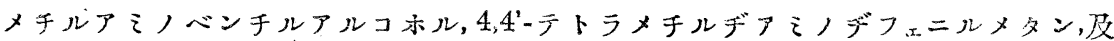

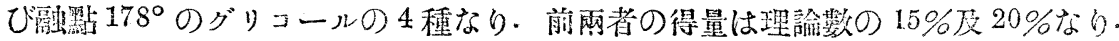

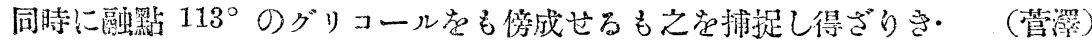
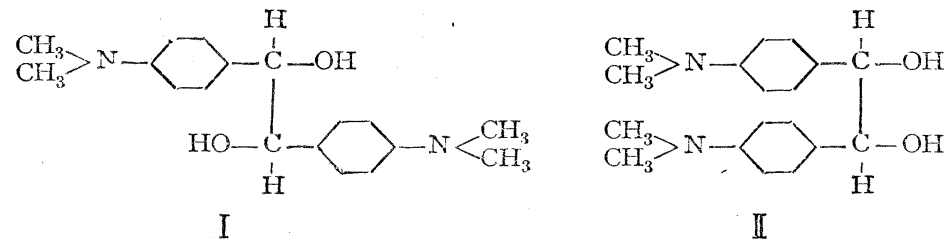

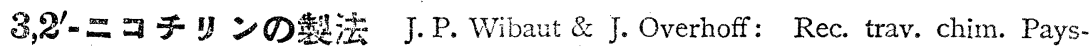

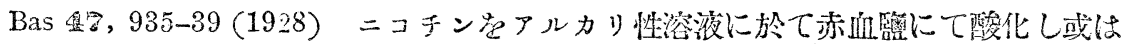
酸化銀を以て酸伦する時脫水素化行はれて N-メチルー(3-ピリヂル)-2ーピロール

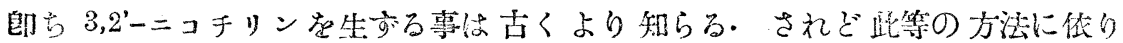

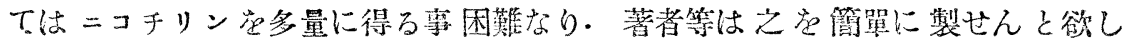

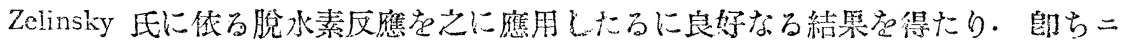

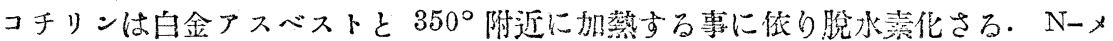
チルピロールを赤熱する時は 亦上記の場合に於て得らるるものは未反應(ニコチンとニコチリンのふにして他

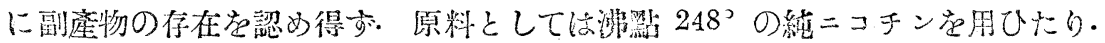
白金アスベストは Löw-Zelinsky 氏に俵る 30\%のもの存使用し之学管中に裝し電

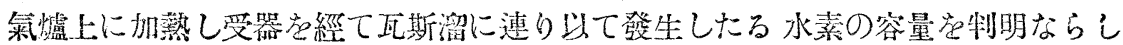
めたり゙・ニコチンは 1 時間に 1.3-2.6g 炎供給するを可とす。䆩驗に依れば盗度 
は 29 ) $-350^{\circ}$ 良好にして水素發生量は 290-293’に於て瑟諭數の $50 \%, 316-320^{\circ}$

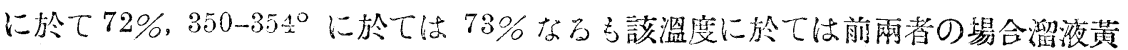
色なるに反し褐色となり更に 406-410”に於ては水素の發生量 $16 \%$, にして溜㴕

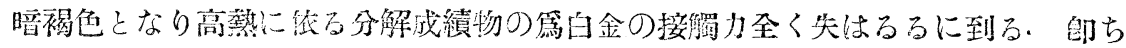

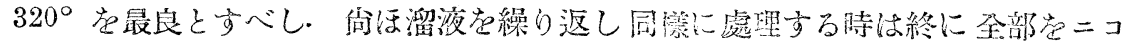

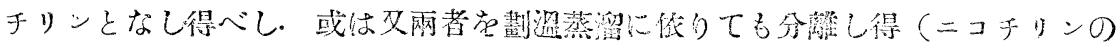

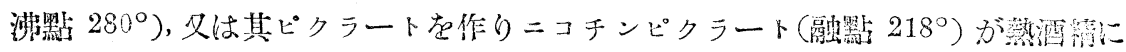

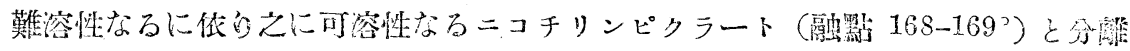
す万禁走得.

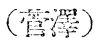

$E^{\circ}$ a

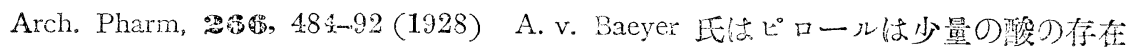

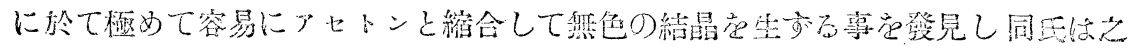

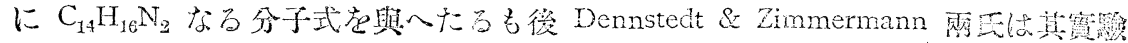

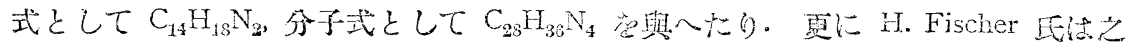

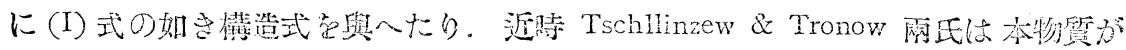

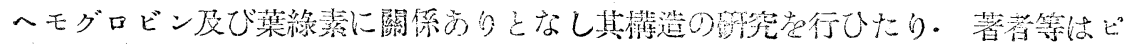

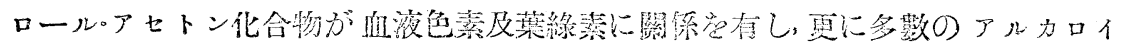

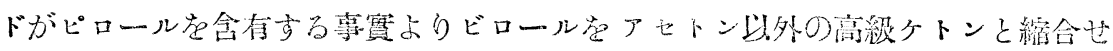

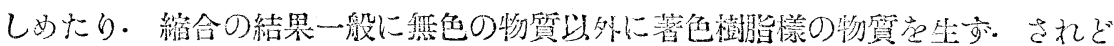

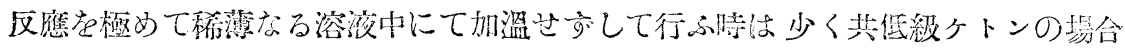
には著色物質の生成量热制限し得. 其反應の經過次式の如し.アセトンの琹合に

$$
4 \mathrm{C}_{4} \mathrm{H}_{5} \mathrm{~N}+4 \mathrm{C}_{3} \mathrm{H}_{6} \mathrm{O}=\mathrm{C}_{28} \mathrm{H}_{36} \mathrm{~N}_{4}+4 \mathrm{H}_{2} \mathrm{O}
$$

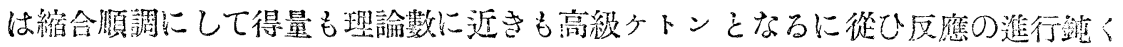
樹脂㨾物質の生成量增加し從て目的物の得量琵くなる。される゙此の琪合に於ても

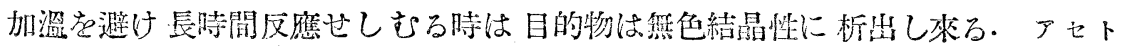

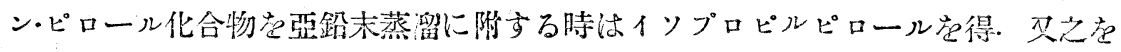

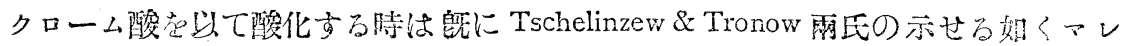
インイミドを得,メチルエチルケトン・ビロールに於ても同樣マレインイにド壱生 まるより見ればケトンはビロールの メヂルピロールはアセトンと同樣なる4ーピロール核含有繀合體苍生ざざるに依り ても磼め得. 郎ち本化合ぱ

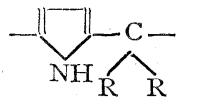
なる核を有せざる可ら亦. 而して先づピロール2 分 タン $\mathrm{C}_{4} \mathrm{H}_{4} \mathrm{~N}-\mathrm{CR}_{2}-\mathrm{C}_{4} \mathrm{H}_{4} \mathrm{~N}$ を生じ此の 2 分子の丵ける $\alpha$ 一值置に第三のケトンが縮

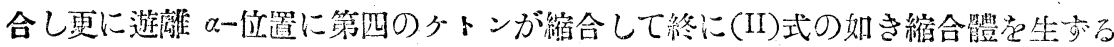


なり・本物質以外に生ずる著色物質は共䡉二重結合觉有する篇に起るものの如く ケトンとピロールが (III) 式の如く結合するか或は笔づ (IV) の如き化合物を生じ

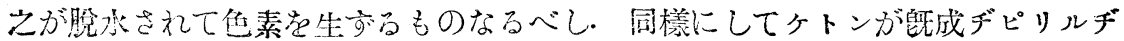
アルキルメタン觉縮合して同樣なる色素觉生じ得べし.

(管漛)<smiles>CC1=C(C)C(C)(C)C2=C1C=CNC2</smiles>

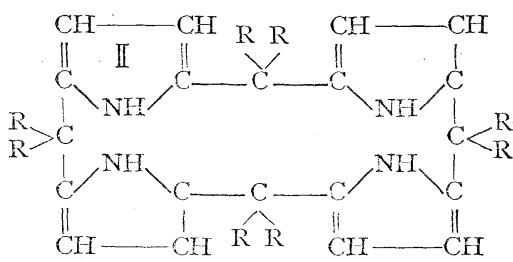<smiles></smiles><smiles>[R19]C(=[W])c1ccc[nH]1</smiles>

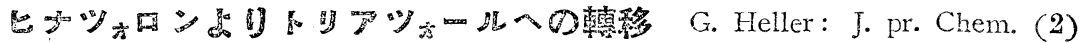

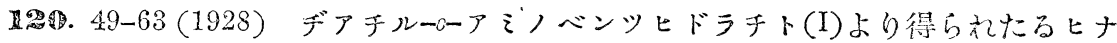

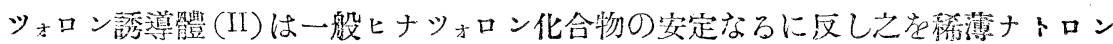

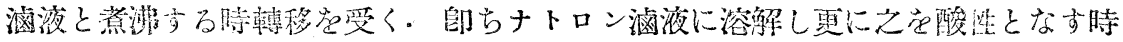

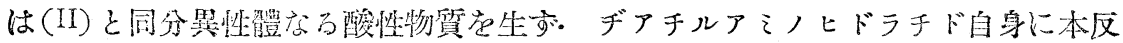
應总應用するに上の埸合の加く圓滑に反應せざるを兒れば先づヒナッォロン縮合

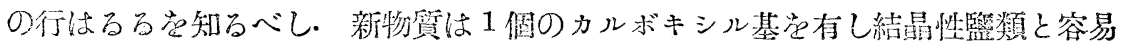

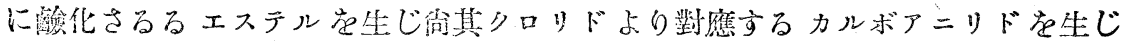

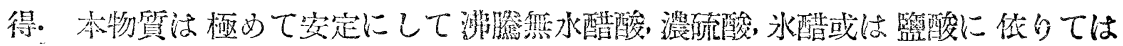
$200^{\circ}$ にては作用を受け亦，又アルカリ性溶源に於ては亞鉛末或ば過マンガン酸

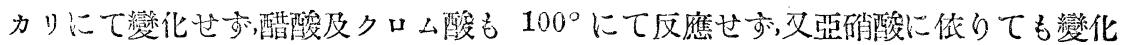
を受けす。沶記の事實より想像するに本物質はトリアツォール環觉有するものな

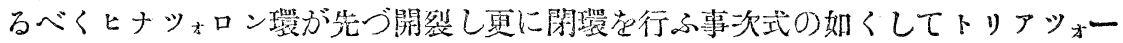

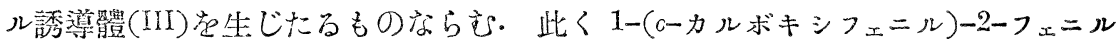
-5ーメチルー1,3,4-トリアツォール(IV) は 2-フェニルー3ーアセチルアミノー4ーヒナツォ<smiles>[R1]C(=O)NNC([R])=NC1CCCCC1C(=O)O</smiles><smiles>[R]c1nnc([Y13])n1Cc1ccccc1C(=O)O</smiles>

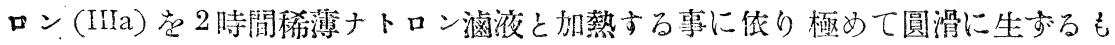
之と同分異性なる 2-メチルー1ーベンツォイルアミノー4ーヒナツォロンが同樣なる轉 